\title{
Effect of Dowel Material and Design on the Fracture Resistance of Premolars
}

\section{Nadia Z. Fahmy*}

Faculty of Dentistry, 6 October Modern Sciences and Arts University, Egypt

\section{Abstract}

Statement of problem: A dowel is essential to retain the core in case of severe tooth destruction. However, the placement of a dowel and core may actually weaken teeth and affect their failure pattern depending on their material properties and stress transfer.

Purpose: The present study compared the fracture resistance and failure pattern of endodontically treated premolars with different amounts of tooth destruction restored with dowels of different materials: a heat pressable ceramic (IPS e.max) and glass fiber reinforced dowels with 3 dowel space designs.

Materials and methods: Ninety single rooted premolars of similar dimensions were selected and divided at random into 9 groups $(n=10)$ Group 1: Sound teeth (Control group), Group 2: Reduced sound teeth with 60 taper and a $1 \mathrm{~mm}$ shoulder FL. Groups (3-9) were endodontically treated and divided as follows: Group 3: Restored teeth with minimal endodontic access. Groups 4, 5 and 6 restored using a pressable ceramic dowel and core while groups 7, 8 and 9 were restored using fiber dowels and composite cores. The samples were loaded to fracture and the mode of fracture for each group was examined. The recorded values were tabulated and statistically analyzed.

Results: Group 5 (tapered ceramic) showed the highest fracture mean values followed by group 6 (parallel ceramic). Group 4 (parallel tapered ceramic) showed statistically similar values to group 1 (sound teeth).Group 2 (Reduced sound teeth) registered $20 \%$ reduction in fracture resistance when compared to group 1 (sound teeth). Group 3 (minimal endodontic access) showed statistically similar values to group 2. Fiber groups 7, 8 and 9 displayed statistically similar mean fracture resistance values, which were 30\% lower than those of groups 2 and 3 .

Conclusions: Reduction of sound teeth resulted in $20 \%$ decrease in their fracture resistance. Endodontically treated premolars with minimal access, restored with composite, maintained the same values as sound reduced teeth. Pressed ceramic bonded dowel and cores with three dowel designs displayed higher resistance means than sound reduced teeth; however, most failures were unfavorable. Fiber dowels and composite core groups registered approximately $70 \%$ of the values of sound reduced teeth but all failure patterns were favorable.

Keywords: Dowel material; Design; Fracture resistance; Premolars

\section{Introduction}

Endodontically treated teeth are more susceptible to biomechanical failure than vital teeth $[1,2]$. They have been shown to exhibit a significantly shorter service life when compared with vital teeth [37]. The failure of the majority of restored pulpless teeth was reported to be prosthetic rather than biological [8]. The generally accepted explanation for their increased failure rate, is the substantial decreased structural integrity of the tooth during endodontic access, dowel-space preparation, and cavity preparation $[9,10]$.

A dowel is essential to retain the core in case of insufficient dentin to support a crown restoration [11]. However, the placement of a dowel and core does not increase the fracture resistance of endodontically treated teeth [5], but may actually weaken them [6,7]. In spite of this weakening effect, the use of a dowel to anchor the buildup of a severely damaged non vital tooth, is usually indispensable, due to poor mechanical resistance of the remaining tooth structure [11,12]. Ideally, a dowel should minimize the stress on a tooth by distributing occlusal loads evenly, and allowing its easy removal in case of retreatment $[8,9]$. In addition, its elastic modulus should have physical characteristics similar to dentin to avoid root fracture [10,12]. It should also be biocompatible and adhere well to tooth structure [13].

There are two types of dowels in use, custom-made and prefabricated. In case of endodontically treated anterior teeth, with moderate to severe destruction, cast dowels and cores have been described as the restorative method of choice [14,15]. Conversely, molars often perform satisfactorily with direct cores retained by engaging the pulpal chamber and a portion of the root canals [16,17]. Premolars may be restored with either custom cast dowels and cores or prefabricated dowel (s) with direct cores [18]. Cast dowels are best applied to single-rooted teeth and remain an integral component of prosthodontic treatment [19]

Prefabricated dowels are popular because of their low cost, speed and simplicity [20]. They are usually made of metals or nonmetals, such as ceramic and fiber dowels. However, with metal dowels, roots are prone to fracture, due to their high elastic moduli compared to dentin $[8,12]$. Fiber-reinforced composite (FRC) dowels are made of composite in which fibers are embedded in a resin matrix to enhance mechanical properties [9]. In addition to the esthetic qualities of glass and quartz fiber dowels, their adhesive strengths to composite resin cores are superior to those between composite resin and metal dowels [10]

A key element of tooth preparation when using a dowel and core is the incorporation of a ferrule $1.5-2 \mathrm{~mm}[21,22]$. The effectiveness of the

*Corresponding author: Nadia Z. Fahmy, 6B, Ahmed Sabry St., Zamalek, 11211, Cairo Egypt, Tel: 202-27357608; Mob: 20123470663; E-mail: nadiafahmyz@hotmail.com

Received August 02, 2011; Accepted January 13, 2012; Published January 16 2012

Citation: Fahmy NZ (2012) Effect of Dowel Material and Design on the Fracture Resistance of Premolars. Dentistry 2:116. doi:10.4172/2161-1122.1000116

Copyright: @ 2012 Fahmy NZ. This is an open-access article distributed under the terms of the Creative Commons Attribution License, which permits unrestricted use, distribution, and reproduction in any medium, provided the original author and source are credited. 
ferrule has been evaluated by various methods [21,23-32], The majority of studies regarding the effectiveness of a ferrule support the need for at least $1.5 \mathrm{~mm}$ of ferrule height, encompassing the entire circumference of the tooth [33-36]. In the absence of a ferrule, occlusal forces are concentrated at the junction of the dowel and core, causing the fracture of the dowel [37].

Dowels maybe parallel sided or tapered. Assif et al. [38] reported that the design of the dowel did not influence resistance to fracture if the core was covered with a complete cast crown that extended two $\mathrm{mm}$ apical to the finish line of the core. However, controversy exists concerning dowel designs, materials and failure modes, even in the presence of ferrules and crowns. Research suggests that clinicians should focus more on factors affecting resistance to root fracture [2], by maintaining tooth structure bulk [37]. Tapered threaded dowels produce the greatest dentinal stress surrounding the dowel [39]. Some parallel sided dowels have been modified whereby parallelism is maintained but their diameters are reduced in their apical portions where the root is generally thinner [37]. Active dowels are more retentive but generate unfavorable stresses and predispose the root to fracture [39-41]. Parallel-sided passive dowels cemented with resin cement are optimal for retention and stress distribution [42-45].

The integration of adhesive techniques into dowel and core procedures has altered dowel designs and resulted in the development of new materials. It is now possible to have a bonded tooth dowelcore-crown "monobloc" type of restoration instead of an assembly of heterogeneous materials [46]. The esthetic properties of materials used for preprosthetic foundations are an important concern for clinicians. Light conducting fiber and all ceramic dowels possess superior esthetics, however; each system has its inherent deficiencies. Some authors believe that dowels and cores of high stiffness provide more even distribution of stresses as they resist deformation [47,48], while, others believe that dowels and core of low stiffness are preferable as they transfer less stresses to the surrounding dentine [49-52].

IPS e.max Press is a recently developed lithium disilicate glassceramic ingot for the heat press technology having a flexural strength of $400 \mathrm{MPa}$. This study will compare the fracture resistance of endodontically treated premolars using pressable ceramic IPS e.max and three fiber dowel and composite cores with three different designs to determine the most favorable fracture resistance and failure pattern of these systems.

\section{Materials and Methods}

Ninety single rooted premolars of similar dimensions were selected for this study and stored in artificial saliva. The teeth were divided at random into nine groups of ten each as follows: Group 1: Sound teeth (Control group), and Group 2: Reduced sound teeth with $6^{\circ}$ taper, $1 \mathrm{~mm}$ shoulder FL. Root canal treatment was performed for the remaining teeth $(n=70)$ using gutta percha cones (Dentsply Detrey, Germany) and eugenol-free sealer (Topseal, Dentsply, Maillefer) for obturation using the lateral condensation technique. Groups (3-9) were divided as follows: Group 3: teeth were endodontically treated with minimal access and maximum conservation of tooth structure. The remaining sixty premolars (4-9) were decapitated $2 \mathrm{~mm}$ coronal to the cemento-enamel junction. A custom-made paralleling machine was used to standardize ferrule taper at $6^{\circ}$ and a $1 \mathrm{~mm}$ shoulder finish line was placed $2 \mathrm{~mm}$ cervical to it. Ferrule dimensions were set at 2 $\mathrm{mm}$ height, $5.5 \mathrm{~mm}$ buccolingual and $3.5 \mathrm{~mm}$ mesiodistal dimension using a caliper at predetermined locations (Figure 1).

Gutta percha was removed from the remaining sixty teeth (Gates

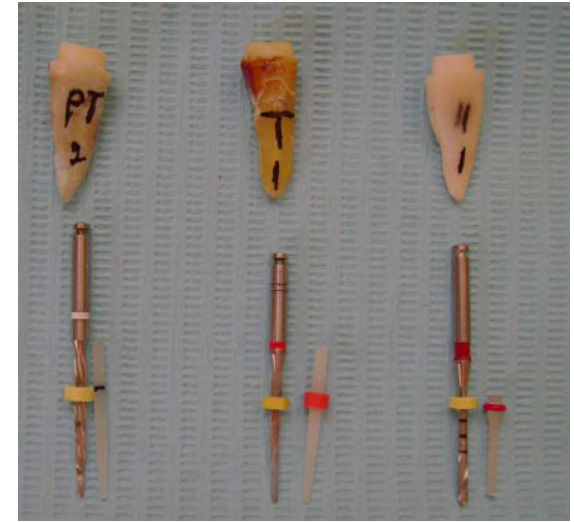

Figure 1: $2 \mathrm{~mm}$ ferrule preparation, fiber dowels with their corresponding drills showing different designs.

Gladden, \# 3, Dentsply, Maillefer). The dowel space was adjusted to be $11 \mathrm{~mm}$ flush with the ferrule by the help of a rubber stopper, leaving a minimum of $4 \mathrm{~mm}$ apical gutta percha [53]. The teeth were divided into 2 groups, according to the dowel and core material: groups 4,5 and 6 were restored using heat pressable Emax ceramic (Ivoclar, Vivadent, Schaan, Liechtenstein), . while groups 7, 8 and 9 were restored using glass fiber dowels and composite cores. The three most recognized dowel designs were represented in each material group using the drills for the corresponding fiber system: Parallel tapered (Dowelec, Ivoclar, Germany), Tapered (Rely X, 3M ESPE, Seefeld, Germany) and Parallel (Lux, Coltene, Whaledent). All dowel preparation lengths were adjusted to $11 \mathrm{~mm}$.

\section{Ceramic dowel and core sample preparation}

A wax pattern of the dowel space was done with a corresponding wax core built to the dimensions of the reduced natural teeth within group 2: $2 \mathrm{~mm}$ core height at the central groove and $3 \mathrm{~mm}$ at the reduced cusp heights in 2 planes with an approximate angle of $120^{\circ}$ between both cusps using a readymade celluloid former. Spruing and investing of the patterns was done as recommended by the manufacturer. The invested patterns were placed in the burnout $\left(850^{\circ} \mathrm{C}\right)$, and then pressed in the EP600 Combi Press furnace at the program recommended for E-max Press. After completion of the press cycles and cooling, the dowels and cores were retrieved, divested and seated on the corresponding teeth. The sprues were cut with diamond discs and coolant to prevent heat generation.

The dowels were acid etched using 9\% buffered Hydrofluoric acid, (Ivoclar, Vivadent, Liechtenstein) then rinsed and dried. They were then coated twice with ceramic primer (Monobond-S, Ivoclar, Vivadent) and dried ready for bonding with Rely-X Unicem (3M, ESPE).

\section{Fiber dowel and composite core preparation}

All the fiber dowels were shortened to $13 \mathrm{~mm}$ length using a diamond disc to extend $2 \mathrm{~mm}$ within the core. The dowels were cleaned with alcohol and silanated (Monobond-S, Ivoclar, Vivadent). All the dowels were cemented to their corresponding teeth using Rely Unicem Aplicap (3M, ESPE) adhesive resin cement. Excess cement was removed before curing (LED, Trax Lighting, Ca, USA) for 40 seconds.

\section{Composite core construction}

The root face was etched for 15 seconds, rinsed and dried (Scotchbond, 3M, ESPE)Two coats of Adper adhesive (Single bond2, 
3M,ESPE)were applied, dried gently for 5 seconds and cured for 10 seconds using LED. Filtek Z350, (3M, ESPE) a flowable composite, was used to fill the space surrounding the dowels. A celluloid strip was placed encircling the ferrule using a matrix holder and composite (Filtek Z250, 3M, ESPE) was packed to build the core. Curing was done for 40 seconds. Core adjustments and shaping were then done using diamond points and a caliper followed by polishing.

The roots were dipped in molten wax (0.2-0.3 mm thickness) and embedded in acrylic resin (Acrostone, Egypt) poured inside a hollow teflon cylindrical block former. After hardening, the wax was flushed with hot water and the root spaces were injected with 3M Imprint II (3M ESPE) wash impression material and reembedded inside the epoxy base simulating the periodontal ligament.

\section{Fracture resistance test}

The samples were individually and vertically mounted in the lower fixed compartment of a computer-controlled materials testing machine. (Model LRX-Plus; Lloyd Instruments Ltd., Fareham, UK) with a load cell of $5 \mathrm{kN}$ and data were recorded using computer software (Nexygen-MT; Lloyd Instruments).The samples were loaded in compression until fracture at a crosshead speed of $0.5 \mathrm{~mm} / \mathrm{min}$. Load was applied by a steel rod with round tip $3.6 \mathrm{~mm}$ diameter (the midrange of cuspal radii 2 to $4 \mathrm{~mm}$ ) attached to the upper movable compartment of the machine. Mode of fracture for each group was examined using a magnifying lens $(3 \mathrm{x})$ and the pattern of failure was described as favorable or unfavorable depending on the ability to retreat the tooth. Data were presented as means and standard deviation (SD) values. One way Analysis of Variance (ANOVA) was used for comparison between means. Tukey's dowel-hoc test was used for pairwise comparison between the means when ANOVA test was found significant. The significance level was set at $P \leq 0.05$. Statistical analysis was performed with SPSS $15.0^{\circ}$ (Statistical Package for Scientific Studies) for Windows.

\section{Results}

Table 1 shows that sound teeth recorded significantly higher fracture resistance values than sound reduced teeth and endodontically treated teeth with minimal access. No statistically significant difference appeared between the mean values of reduced sound teeth (Group 2) and endodontically treated teeth with minimal access. (Group 3) (Table1) (In addition, no statistically significant difference was evident between Group 1(Control group) and Group 4. Table1) Group 5 (Tapered) E.max Ceramic resulted in statistically the highest significant mean resistance values within the ceramic groups followed by Group 6 (parallel) and 4 (Parallel tapered) (Table1) Finally, no statistically significant difference was displayed in the fiber and composite groups between Group 7, Group 8 and Group 9. Those shared statistically the lowest mean values of all the groups (Table1).

\section{Discussion}

Controversy exists regarding the quality of dentin in endodontically treated teeth. The properties of restored or endodontically treated teeth differ from those of vital sound teeth and may account for their high failure rates [54]. Helfer et al. [55] found that pulpless teeth had $9 \%$ less moisture than vital teeth, which accounted for only $5 \%$ reduction in their stiffness and modulus of elasticity [56], whereas tooth removal in MOD preparations reduced teeth stiffness by $60 \%$ [57]. Carter et al. [58] observed lower shear strength (14\%) and toughness. Sedgely et al. [59] however, suggested that it was the cumulative loss of dentin and the pressoreceptive mechanism, and not the endodontic procedures that affected their clinical performance.

Sound premolars, in group 1, were considered as control group, possessing 100\% fracture resistance values. (1029.4N) Reduction (group 2), seemed to reduce premolar fracture resistance by $20 \%$. $(803.4 \mathrm{~N})$ Moreover, endodontically treated premolars with minimal access restored with adhesive composite (Group 3), showed statistically similar mean values.(891.7N) This finding suggests that the remaining tooth structure controls the strength of teeth as suggested by Sedgely et al. [59]. The presence of buccal and palatal cusps with intact marginal and distal ridges result in a continuous circle of sound tooth structure providing the strength required for maintaining crown and tooth integrity [60].

The six remaining groups (4-9) were decapitated $2 \mathrm{~mm}$ coronal to

\begin{tabular}{|c|c|c|c|c|}
\hline Dowel \& Core material & Group & Mean & SD & $P$-value \\
\hline & $\begin{array}{c}\text { Group } 1 \\
\text { Intact Teeth }\end{array}$ & $1029.4^{c}$ & 67.1 & \multirow{9}{*}{$<0.001^{*}$} \\
\hline & $\begin{array}{c}\text { Group } 2 \\
\text { Reduced teeth }\end{array}$ & $803.4^{d}$ & 30.1 & \\
\hline & $\begin{array}{c}\text { Group 3 } \\
\text { Reduced_minim Rt canal access }\end{array}$ & $891.7^{d}$ & 19.3 & \\
\hline \multirow{3}{*}{$\begin{array}{l}\text { Ceramic dowel and core } \\
\text { (E.max) }\end{array}$} & $\begin{array}{c}\text { Group } 4 \\
\text { Parallel Tapered- E.max Ceramic }\end{array}$ & $1088^{c}$ & 29.3 & \\
\hline & $\begin{array}{c}\text { Group 5 } \\
\text { Tapered E.maxCeramic }\end{array}$ & $1434.4^{\text {a }}$ & 28.4 & \\
\hline & $\begin{array}{c}\text { Group } 6 \\
\text { Parallel E.max Ceramic }\end{array}$ & $1314.4^{b}$ & 53.7 & \\
\hline \multirow{3}{*}{ Composite core and Fiber Dowel } & $\begin{array}{c}\text { Group } 7 \\
\text { Dowelec-PT-Composite }\end{array}$ & $512.3^{e}$ & 16.2 & \\
\hline & $\begin{array}{c}\text { Group } 8 \\
\text { Rely X-Tapered-Composite }\end{array}$ & $545^{e}$ & 45.1 & \\
\hline & $\begin{array}{c}\text { Group } 9 \\
\text { Lux -Parallel - Composite }\end{array}$ & 542.9 e & 22.8 & \\
\hline
\end{tabular}

*: Significant at $\mathrm{P} \leq 0.05$, Means with different letters are statistically significantly different according to Tukey's test

Table1 shows that sound teeth recorded higher fracture resistance values than sound reduced teeth and endodontically treated teeth with minimal access. No statistically significant difference appeared between the mean values of reduced sound teeth and endodontically treated teeth with minimal access. Tapered ceramic group displayed the highest significant mean resistance values within the ceramic groups followed by the parallel and parallel tapered groups. Finally, the fiber and composite groups showed statistically similar results.

Table 1: ANOVA and Tukey's tests for the comparison of Fracture resistance - Means between the nine groups 
the cemento-enamel junction, which caused a significant loss of their coronal tooth bulk, necessitating the use of a dowel to anchor the core material and rebuild them as suggested by many authors $[11,12]$. The teeth in groups 4,5 , and 6 were restored with ceramic dowels and cores, but dowel spaces were modified by using three different fiber dowel drills. All possessing significantly different mean values. Tapered ceramic group 5 displayed the highest significant mean resistance values $(1434.4 \mathrm{~N})$ within the ceramic groups followed by the parallel $(1314.4 \mathrm{~N})$ and whereas Parallel tapered groups showed the least mean value $(1088 \mathrm{~N})$ similar to intact teeth. It is noteworthy to mention that due to some flaring in natural premolar morphology, the coronal parts of the dowel spaces were flared in all the pressed ceramic groups, giving a relative taper to all the dowels irrelevant of the drill used (Figure 2) but perfectly adapted to the dowel space morphology.

An ideal dowel should have an optimal combination of resilience, stiffness, flexibility and strength. It should be resilient enough to cushion impacts by stretching elastically, thereby reducing the resulting stresses to the root returning to normal without permanent distortion. Stiffness would make the dowel not distort or bend under masticatory forces. Finally, the perfect dowel should combine an ideal level of flexibility and strength in a narrow diameter structure, which is dictated by root canal morphology. The stiffness, of a material is an inherent physical property of a material regardless of size. Flexion of a dowel depends on both the diameter of a dowel and its modulus of elasticity. Roots flex under forces, which is a function of both the modulus of dentin and the diameter of the root [61]. Dentine is relatively flexible while, dowels may be flexible or stiff. Rigid dowel systems traditionally were designed to protect tooth structure from fracture by dissipating functional force along the length of the root and periodontal membrane. Forces from a stiff dowel are transmitted to the root apex of the dowel. Thus, attempts to add a stiff dowel in a weak root can weaken it further due to force concentration by a stiff rod in a more flexible material, resulting in root fracture [61]. However, the load to failure of the formed "compound structure" appears to be equal to the strength of the natural tooth in group 4 or even stronger in both groups 5 and 6 but accompanied with catastrophic failure.

The pressed ceramic group could be compared morphologically to cast metallic cores, in the sense that they closely fit the internal tooth anatomy and produce a closely fitting dowel and core of the same composition. IPS e.max is a recent glass ceramic with reported strength by its manufacturer of $400 \mathrm{MPa}$. It is composed of lithium disilicate. This high strength along with its modulus reaching $95 \mathrm{Mpa}$ classifies it as a rigid material. In contrast, the former Cosmodowel, is composed of $\mathrm{ZrO}_{2}$ ceramic and possess a cylindrical root dowel with a conical tip.

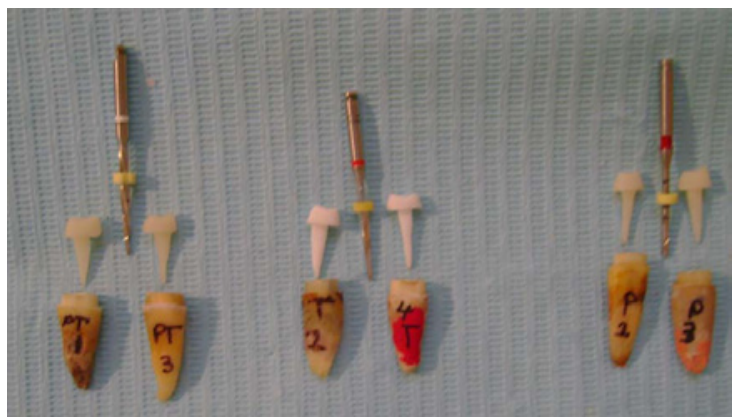

Figure 2: Pressed ceramic dowels and cores before cementation. They appear to possess similar designs. This is probably due to the internal morphology of premolars along with flaring during root canal shaping.
It is claimed to have a flexural strength of $900 \mathrm{MPa}$ and a modulus of $210 \mathrm{GPa}$ [62]. This high value often caused catastrophic unfavorable root fractures during testing. In addition, the strength and integrity of the bond between zirconia and its pressed ceramic core was observed to be unreliable [46].

Within the ceramic groups, the internal anatomy seemed to affect the recorded fracture resistance mean values. The tapered group 5 showed the highest fracture mean values followed by the parallel group 6 . The parallel-tapered group 4 showed statistically similar values to the intact group 1. However, failure in groups 5 and 6 was unfavorable agreeing with the suggestions that both parallel and tapered dowels affect stress distribution of dowels. 43,44 The fact that the recorded fracture resistance values were higher than intact teeth may have been due to the high flexural strength and rigidity of the bonded ceramic which provided more even stress distribution as they resist deformation under loading contrary to the fiber dowel groups $[47,48,63]$. Furthermore, Ko et al. and Davy et al. $[64,65]$ studied the effects of dowels on dentin stress distribution in pulpless teeth using strain models and concluded that dowels reduced maximum dentin stress by $30 \%$ when the teeth were loaded vertically.

Failure patterns within the ceramic groups were mostly unfavorable. However, approximately $60 \%$ of the fractures in the parallel tapered group were retreatable, as the fracture levels were mostly in the coronal part of the root and most of the ferrule. Four of the fractures were longitudinal, splitting the root obliquely. All the fractures in the tapered group and the parallel group were unfavorable, due to the level of fracture involving variable levels of the root, and shattering the root face and ferrule into multiple broken small fragments rendering their retreatment impossible $[29,63,66,67]$. These findings agree with previous reports stating that upon loading tapered dowels high wedging forces are produced while, cylindrical dowels create high apical stresses [68-70]. In all the ceramic groups the cores were missing, suggesting that most of the stress concentration involved the dowelcore connection. The fracture was cohesive between the core and the dowel material at their junction. This agrees with the observations of Yaman et al. [71] about stiffer core materials shifting the load from the apex to the coronal region. Others disagree, claiming that forces from a stiff dowel are transmitted to the root apex of the dowel [61]. E.max possesses a modulus of $95 \mathrm{MPa}$ only, this value is half that of Zirconia and much less than that of a cast metal.

Dowel and core failures from root fractures have been reported in the range of $3-10 \%$ of all tooth build up failures [46,72]. Vertical and oblique root fractures were commonly observed by many authors in fracture testing of cast metal and zirconia dowel and cores $[48,63,73]$, Root fractures have been attributed to high rigidity of the dowel materials used. Contemporary adhesive dentistry allows for the bonding of cores to the remaining tooth structure [76,77]. Bonding techniques augment the mechanical retention of a core, but should not be used as the sole means of retention [78] Failure can occur because of root fracture, dowel fracture, core fracture or cement failure. Tooth fractures associated with dowel and core failure frequently render the tooth non-restorable necessitating its extraction. Retreatment is possible only if the fracture is coronal and dowel retrieval is possible without further tooth mutilation $[11,54,79]$.

Fiber groups 7, 8 and 9 displayed statistically similar mean fracture resistance values, which were statistically lower than all the other tested groups 1-6. These values were $70 \%$ of those recorded by sound reduced group 2, and almost half the mean values of the ceramic groups. This value could have possibly been higher had the bonding between the 
fiber dowel and the composite core been stronger to resist occlusal loading. Multiple authors documented similar lower values for carbon fibers as compared to cast metal dowel and core $[61,63,80,90]$. This may be explained by fiber dowel compression due to its flexibility and that of the elastomer simulating the periodontal membrane, during vertical loading, which simulates the direction of premolar loading during function $[61,64,65]$. Dowel flexure under occlusal loads can result in micromovement of the core, disruption of the cement seal and leakage or loss of the core and crown [18]. On the other hand, low modulus dowels absorb more forces, transmit less force to the root than stiff dowels but fail at lower levels. Their excessive flexing and micromovement are a risk in teeth with minimal remaining tooth structure. They are more beneficial in teeth with 3-4 $\mathrm{mm}$ of remaining axial dentin, which provides cervical stiffness in tooth/dowel/ core complex [61].

Within groups 7, 8 and 9 all the fractures involved only the core, which agrees with the findings of Martinez-Insua et al. [63] The core split longitudinally leaving the fiber dowel and the remaining part of the core attached to the ferrule. This type of adhesive failure in the core-dowel interface was probably due to concentration of stresses at this site and the lack of adequate bonding between both allowing for an adhesive type of fracture along their interface. All the fractures in the composite core were favorable (adhesive). This suggests that the glass fiber dowels were superior to ceramic dowels in terms of favorable fracture expectations and retreatment possibility. Moreover, fiber dowels are easily retrieved with rotary instruments.

The composite core fractures could be related to the fiber dowels possessing elastic moduli similar to dentin (14.2 Mpa) [81,82]. They possess a modulus allowing them to flex under loading thus concentrating the stresses at their interface with the composite cores (Figure 3). In addition, minor differences in moduli between the composite core, fiber dowel, cement and dentine could have accounted for minor movements in the components causing stresses at their interfaces [61]. The head design in all fiber groups was similar and smooth, except for the Paradowel group, which was rounded but smooth. This is contrary to the former metal prefabricated dowel heads, which allowed for some mechanical interlocking between the dowel head and the core material. The design of the dowel head and its extension in the core influences the failure loads [83].

Most of the bonding between the fiber dowel and the core was chemical through the adhesive used and silane priming. Dentin, resin cement, dowel and core together are often described as forming "strong monoblock" restorations. The adhesive cement is the unifying bond between these components. However, failure of the adhesive bonding of the dowel in the dentin results in debonding failures of the dowel/ core/ crown. Weakness in the adhesive bond between cement/dowel/ dentin has been clinically reported [84-87]. Decementation of fiber dowels have also been reported to be the result of adhesive fractures between the resin cement and the dentin wall [87] or at the cement/ dowel junction $[85,86]$. Some additional micromechanical bonding could be tried in further studies to enhance bonding by sandblasting the fiber dowels with $50 \mu \mathrm{m} \mathrm{Al}_{2} \mathrm{O}_{3}$ particles at reduced pressure. In that case, failure pattern could change and fracture resistance values might increase.

Regarding the effect of internal design on the cast ceramic dowel and core, significant differences were evident in their fracture resistance mean values. The fact that the ceramic was pressed implies that the internal dowel space anatomy played a significant role. The tapered group appeared to possess the highest mean values followed

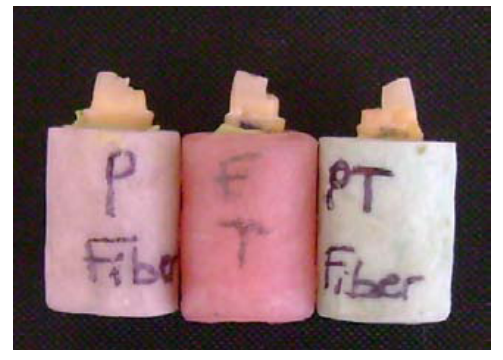

Figure 3: Fractured composite cores, leaving almost half the cores bonded to the fiber dowels. Fracture extended along the core dowel interface in all samples.

by the parallel group. Those were higher than the values of the control intact teeth but resulted in unfavorable catastrophic failures. The parallel tapered group showed mean values close to those of sound teeth and the most favorable mode of fracture of the three ceramic groups. E.max is claimed by the manufacturer to possess a modulus of elasticity of $95 \mathrm{GPa}$; this value is about six times that of the fiber or dentine allowing for dowel rigidity and less bending. The ceramic dowel and core is one piece, totally bonded to the tooth and therefore able to increase its fracture resistance by absorbing most of the stresses. The favorable transfer of stresses to the tooth however, appears to be in the parallel tapered group, which agrees with the literature in case of metallic dowel systems. However, in the current study, the whole assembly is adequately bonded together through ceramic etching of the ceramic and silanization thus acquiring both mechanical and chemical bonding between the dowel-resin-cement and tooth structure.

Our golden standards of comparison remain cast metallic dowels and cores with their long-term use as dowel-and-core foundations. They possess superior physical properties [63]. However, their high elastic modulus were reported to cause stress concentrations within the surrounding radicular dentin, resulting in root fractures $[25,29,89]$. It has also been observed that they have a tendency to cause tooth fracture, whereas composite-resin cores and metal dowels are more predisposed to core failure [88,90-94]. However, the effectiveness of these strengthening mechanisms varies with the prime requirement being adequate bond formation between the reinforcing material and the parent resin, in this case, the composite core and the fiber dowel. In the presence of an inadequate bond, the filler (fiber dowel) may act as an inclusion body and weaken the prosthesis [96]. This could explain the lower fracture resistance values found in these groups estimated at $70 \%$ of those recorded in groups 2 .

The effect of the design of the fiber dowel on the fracture resistance of the teeth in the current study was almost negligible due to two factors. First the level of the fracture and secondly the dowel shortening. This was performed as recommended by the manufacturer, from the coronal part of the dowel, which also affected their design. Initially the dowel length is $20 \mathrm{~mm}$ and by shortening it to $11 \mathrm{~mm}$ from its coronal part, the difference in dowel design was minimal between the parallel tapered and the tapered group. One could regard both as being almost tapered all along their length; the only difference could have been regarding the parallel group, which was also wider coronally than apically.

Various in vivo and in vitro studies claimed that the presence of a crown caused the differences between various dowel systems to disappear $[21,75,97]$ yet, wide spread studies report significant differences in magnitude and failure pattern with different dowel systems even when the teeth were crowned $[50,51,97]$. Crowns, hinder 
Citation: Fahmy NZ (2012) Effect of Dowel Material and Design on the Fracture Resistance of Premolars. Dentistry 2:116. doi:10.4172/21611122.1000116

assessing the direct effects on the mechanical properties of dowel materials. In addition, cracks propagating from the loading point can be more clearly seen without crowns. As in similar previous studies, the compressive load was directly applied to the inclined surfaces of the cores. In this manner, the variations in parameters, such as material structure, shape, length, and thickness, by crown restorations were avoided. It is considered that by eliminating such parameters, the structural integrity and fracture resistance of a dowel-and-core foundation could be tested more precisely [88-94]. However, further studies inclusive of crowns and using the same conditions may be more conclusive in comparing and evaluating the used systems, as crowns have been shown to alter the distribution of forces to the roots in addition to providing bracing action to the tooth [99].

\section{Conclusions}

1. Reduction decreased $20 \%$ of the fracture resistance values of sound teeth.

2. Endodontically treated premolars with minimal access, restored with composite, maintained the same fracture resistance values as sound reduced teeth.

3. Heat pressed ceramic (IPS e.max) recorded higher resistance mean values than sound reduced teeth but displayed mostly unfavorable catastrophic failures.

4. Parallel tapered design of pressed emax ceramic produces more favorable fractures due to better stress distribution along the root.

5. Glass fiber dowels and composite core groups registered $70 \%$ the value of sound reduced teeth and displayed $100 \%$ favorable retreatable fractures.

\section{Clinical Implication}

IPS e.max pressable ceramic presents a clinical alternative to rebuild severely destroyed teeth. However, it is safer to use a parallel tapered drill to shape the dowel space to minimize unfavorable fractures. Moreover, this ceramic possesses a hardness of $5800 \mathrm{Mpa}$ allowing it to be easily retrieved in case of failure and retreatment. This is an in vitro study which has its limitations, however from the obtained results it appears to be worthy of further investigation by dynamic loading, thermocycling in addition to in vivo clinical testing.

\section{References}

1. Caputo AA, Standlee JP (1987) Biomechanics in clinical dentistry. Quintessence, Chicago 185-203.

2. Sorensen JA, Martinoff JT (1984) Intracoronal reinforcement and coronal coverage: a study of endodontically treated teeth. J Prosthet Dent 51: 780-784.

3. Randow K, Glantz PO, Zöger B (1986) Technical failures and some related clinical complications in extensive fixed prosthodontics. An epidemiological study of long-term clinical quality. ActaOdontolScand 44: 241-255

4. Palmqvist S, Soderfeldt B (1994) Multivariate analyses of factors influencing the longevity of fixed partial dentures, retainers, and abutments. J Prosthet Dent 71: 245-250.

5. Leempoel PJ, Käyser AF, VanRossum GM, De Haan AF (1995) The survival rate of bridges. A study of 1674 bridges in 40 Dutch general practices. J Oral Rehabil 22: 327-330.

6. Hämmerle $\mathrm{CH}$, Ungerer MC, Fantoni PC, Brägger U, BürginW, et al. (2000) Long-term analysis of biologic and technical aspects of fixed partial dentures with cantilevers. Int J Prosthodont 13: 409-415.

7. Reuter JE, Brose MO (1984) Failures in full crown retained dental bridges. $\mathrm{Br}$ Dent J 157: 61-63.

8. Vire DE (1991) Failure of endodontically treated teeth: classification and evaluation. J Endod 17: 338-342.
9. Panitvisai P, Messer HH (1995) Cuspal deflection in molars in relation to endodontic and restorative procedures. J Endod 21: 57-61.

10. Reeh ES, Messer HH, Douglas WH (1989) Reduction in tooth stiffness as a result of endodontic and restorative procedures. J Endod 15: 512-516.

11. Jung RE, Kalkstein O, Sailer I, Roos M, Hammerle CH (2007) A comparison of composite post buildups and cast gold post-and-core buildups for the restoration of nonvital teeth after 5 to 10 years. Int J Prosthodont 20: 63-69.

12. Goerig AC, Mueninghoff LA (1983) Management of the endodontically treated tooth. Part 1: Concept of restorative designs. J Prosthet Dent 49: 340-345.

13. Deutsch AS, Musikant BL, Cavallari J, Lepley JB (1983) Prefabricated dowels: a literature review. J Prosthet Dent 49: 498-503.

14. Morgano SM, Milot P (1993) Clinical success of cast metal posts and cores. $J$ Prosthet Dent 70: 11-16.

15. Morgano SM (1996) Restoration of pulpless teeth: application of traditional principles in present and future contexts. J Prosthet Dent 75: 375-380.

16. Nayyar A, Walton RE, Leonard LA (1980) An amalgam coronal-radicular dowe and core technique for endodontically treated posterior teeth. J Prosthet Dent 43: $511-515$

17. Nayyar A (1988) Amalgam corono-radicular buildup for molars and premolars J Clin Dent 1: 41.

18. Morgano SM, Brackett SE (1999) Foundation restorations in fixed prosthodontics: current knowledge and future needs. J Prosthet Dent 82: 643657

19. Bergman B, Lundquist P, Sjogren U, Sundquist G (1989) Restorative and endodontic results after treatment with cast posts and cores. J Prosthet Dent 61: $10-15$

20. Hew YS, Purton DG, Love RM (2001) Evaluation of pre-fabricated root cana posts. J Oral Rehabil 28: 207-211.

21. Sorensen JA, Engelman MJ (1990) Ferrule design and fracture resistance of endodontically treated teeth. J Prosthet Dent 63: 529-536.

22. (2005) The glossary of prosthodontic terms. J Prosthet Dent 94: 10-92.

23. Tjan AH, Whang SB (1985) Resistance to root fracture of dowel channels with various thicknesses of buccal dentin walls. J Prosthet Dent 53: 496-500.

24. Patel A, Gutteridge DL (1996) An in vitro investigation of cast post and partia core design. J Dent 24: 281-287.

25. Saupe WA, Gluskin AH, Radke RA Jr (1996) A comparative study of fracture resistance between morphologic dowel and cores and a resin-reinforced dowe system in the intraradicular restoration of structurally compromised roots. Quintessence Int 27: 483-491.

26. Gegauff AG (2000) Effect of crown lengthening and ferrule placement on static load failure of cemented cast post-cores and crowns. J Prosthet Dent 84: 169179

27. al-Hazaimeh N, Gutteridge DL (2001) An in vitro study into the effect of the ferrule preparation on the fracture resistance of crowned teeth incorporating prefabricated post and composite core restorations. Int Endod J 34: 40-46.

28. Cathro PR, Chandler NP, Hood JA (1996) Impact resistance of crowned endodontically treated central incisors with internal composite cores. Endod Dent Traumatol 12: 124-128.

29. Isidor F, Brandum K, Ravnholt G (1999) The influence of post length and crown ferrule length on the resistance to cyclic loading of bovine teeth with prefabricated titanium posts. Int J Prosthodont 12: 78-82.

30. Libman WJ, Nicholls JI (1995) Load fatigue of teeth restored with cast posts and cores and complete crowns. Int J Prosthodont 8: 155-161.

31. Henry PJ (1977) Photoelastic analysis of post core restorations. Aust Dent $J$ 22: $157-159$

32. Loney RW, Kotowicz WE, McDowell GC (1990) Three-dimensional photoelastic stress analysis of the ferrule effect in cast post and cores. J Prosthet Dent 63 506-512.

33. Stankiewicz NR, Wilson PR (2002) The ferrule effect: a literature review. IntEndod J 35: 575-581.

34. Ferrario VF, Sforza C, Serrao G, Dellavia C, Tartaglia GM (2004) Single tooth bite forces in healthy young adults. J Oral Rehabil 31: 18-22. 
Citation: Fahmy NZ (2012) Effect of Dowel Material and Design on the Fracture Resistance of Premolars. Dentistry 2:116. doi:10.4172/21611122.1000116

35. Barkhordar RA, Radke R, Abbasi J (1989) Effect of metal collars on resistance of endodontically treated teeth to root fracture. J Prosthet Dent 61: 676-678.

36. Hemmings KW, King PA, Setchell DJ (1991) Resistance to torsional forces of various post and core designs. J Prosthet Dent 66: 325-329

37. Burns DA, Krause WR, Douglas HB, Burns DR (1990) Stress distribution surrounding endodontic posts. J Prosthet Dent 64: 412-418.

38. Assif D, Bitenski A, Pilo R, Oren E (1993) Effect of post design on resistance to fracture of endodontically treated teeth with complete crowns. J Prosthet Dent 69: 36-40.

39. Standlee JP, Caputo AA (1992)The retentive and stress distributing properties of split threaded endodontic dowels. J Prosthet Dent 68: 436-442.

40. Standlee JP, Caputo AA, Holcomb J, Trabert KC (1980) The retentive and stress distributing properties of a threaded endodontic dowel. J Prosthet Dent 44: 398-404.

41. Standlee JP, Caputo AA, Holcomb JP (1982) The Dentatus screw: comparative stress analysis with other endodontic dowel designs. J Oral Rehabil 9: 23-33.

42. Standlee JP, Caputo AA (1987) Biomechanics in clinical dentistry. Quintessence, Chicago 185-203.

43. Standlee JP, Caputo AA, Hanson EC (1978) Retention of endodontic dowels: effects of cement, dowel length, diameter, and design. J Prosthet Dent 39: 400-405.

44. Johnson JK, Sakumura JS (1978) Dowel form and tensile force. J Prosthet Dent 40: 645-649.

45. Standlee JP, Caputo AA (1993) Effect of surface design on retention of dowels cemented with a resin. J Prosthet Dent 70: 403-405.

46. Cormier CJ, Burns DR, Moon P (2001) In vitro comparison of the fracture resistance and failure mode of fiber, ceramic, and conventional post systems at various stages of restoration. J Prosthodont 10: 26-36.

47. Asmuussen E, Pentzfeldt A, Heitmann T (1999) Stiffness elastic limit and strength of newer types of endodontic dowels. J Dent 27: 275-278.

48. Butz F, Lennon AM, Heydecke G, Strub JR (2001) Survival rate and fracture strength of endodontically treated maxillary incisors with moderate defects restored with different post-and-core systems: an in vitro study. Int $\mathrm{J}$ Prosthodont 14: 58-64.

49. Akkayan B, Gulmez T (2002) Resistance to fracture of endodontically treated teeth with different dowel systems. J Prosthet Dent 87: 431-437.

50. Akkayan B (2004) An in vitro study evaluating the effect of ferrule length on fracture resistance of endodontically treated teeth restored with fiber-reinforced and zirconia dowel systems. J Prosthet Dent 92: 155-162.

51. Ottl P, Hahn L, Lauer HCh, Fay M (2002) Fracture characteristics of carbon fibre, ceramic and non-palladium endodontic post systems at monotonously increasing loads. J Oral Rehabil 29: 175-183.

52. Fredriksson M, Astbäck J, Pamenius M, Arvidson K (1998) A retrospective study of 236 patients with teeth restored by carbon fiber-reinforced epoxy resin posts. J Prosthet Dent 80: 151-157.

53. Goodacre CH, Spolnik KJ (1995) The prosthodontics management of endodontically treated teeth: A literature review. Part III. Tooth preparation considerations. J Prosthodont 4: 122-128.

54. Stockton LW, Williams PT, Clarke CT (2000) Post retention and post/core shear bond strength of four Dowel Systems. Operative Dentistry 25: 441-447.

55. Helfer AR, Melnick S, Schilder H (1972) Determination of the moisture content of vital and pulpless teeth. Oral Surg Oral Med Oral Pathol 34: 661-670.

56. Reeh ES, Messer HH, Douglas WH (1989) Reduction in tooth stiffness as a result of endodontic and restorative procedures. J Endod 15: 512-516.

57. Gutmann JL (1992) The dentin-root complex: anatomic and biologic considerations in restoring endodontically treated teeth. J Prosthet Dent 67 458-467

58. Carter JM, Sorensen SE, Johnson RR, Teitelbaum RL, Levine MS (1983) Punch shear testing of extracted vital and endodontically treated teeth. $J$ Biomech 16: 841-848.

59. Sedgley CM, Messer HH (1992) Are endodontically treated teeth more brittle? J Endod 18: 332-335.
60. Soares PV, Santos-Filho PF, Martins LM, Soares CJ (2008) Influence of restorative technique on the biomechanical behavior of endodontically treated maxillary premolars. Part1: Fracture resistance and fracture mode. J Prosthet Dent 99:30-37.

61. Cohen S, Hargreaveaves KM (2006) Pathways of the pulp $\left(9^{\text {th }}\right.$ edn),Mosby, Missouri, St Louis 795-807.

62. Holand W, Schweiger M, Frank M, Rheinberger V (2000) A comparison of the microstructure and properties of the IPS Empress 2 and the IPS Empress glass-ceramics. J Biomed Mater Res 53: 297-303.

63. MartÃnez-Insua A, da Silva L, Rilo B, Santana U (1998) Comparison of the fracture resistances of pulpless teeth restored with a cast post and core or carbon-fiber post with a composite core. J Prosthet Dent 80: 527-532.

64. Ko CC, Chu CS, Chung KH, Lee MC (1992) Effects of posts on dentin stress distribution in pulpless teeth. J Prosthet Dent 68: 421-427.

65. Davy DT, Dilley GL, Krejci RF (1981) Determination of stress patterns in rootfilled teeth incorporating various dowel designs. J Dent Res 60: 1301-1310.

66. Drummond JL, Toepke TR, King TJ (1999) Thermal and cyclic loading of endodontic posts. Eur J Oral Sci 107: 220-224.

67. Mannocci F, Ferrari M, Watson TF (2001) Microleakage of endodontically treated teeth restored with fiber posts and composite cores after cyclic loading: a confocal microscopic study. J Prosthet Dent 85: 284-291.

68. Standlee JP, Caputo AA, Collard EW, Pollack MH (1972) Analysis of stress distribution by endodontic posts. Oral Surg Oral Med Oral Pathol 33: 952-960.

69. Cooney JP, Caputo AA, Trabert KC (1986) Retention and stress distribution of tapered-end endodontic posts. J Prosthet Dent 55: 540-546.

70. Assif D, Oren E, Marshak BL, Aviv I (1989) Photoelastic analysis of stress transfer by endodontically treated teeth to the supporting structure using different restorative techniques. J Prosthet Dent 61: 535-543.

71. Yaman P, Thorsteinsson TS (1992) Effect of core materials on stress distribution of posts. J Prosthet Dent 68: 416-420.

72. Goodacre CJ, Spolnik KJ (1994) The prosthodontic management of endodontically treated teeth: a literature review. Part I. Success and failure data, treatment concepts. J Prosthodont 3: 243-250.

73. Akkayan B, Caniklioglu B (1998) Resistance to fracture of crowned teeth restored with different post systems. Eur J Prosthodont Restor Dent 6: 13-18.

74. Kern M, Pleimes AW, Strub JR (1995) Fracture strengths of metallic and all ceramic dowel-and-core restorations. DtschZahnärztl Z 50: 451-453.

75. Assif D, Bitenski A, Pilo R, Oren E (1993) Effect of post design on resistance to fracture of endodontically treated teeth with complete crowns. J Prosthet Dent 69: 36-40.

76. Kanca J $3^{\text {rd }}(1991)$ Dental adhesion and the All-Bond system. J Esthet Dent 3: $129-132$.

77. Donald HL, Jeansonne BG, Gardiner DM, Sarkar NK (1997) Influence of dentinal adhesives and a prefabricated post on fracture resistance of silver amalgam cores. J Prosthet Dent 77: 17-22.

78. Lo CS, Millstein PL, Nathanson D (1995) In vitro shear strength of bonded amalgam cores with and without pins. J Prosthet Dent 74: 385-391.

79. Heydecke G, Mathilde CP (2002) The restoration of endodontically treated single rooted teeth with cast or direct dowel and cores: A systematic review. J Prosthet Dent 87: 380-386.

80. Sidoli GE, King PA, Setchell DJ (1997) An in vitro evaluation of a carbon fiberbased post and core system. J Prosthet Dent 78: 5-9.

81. Stanford JW, Weigel KV, Paffenbarger GC, Sweeney WT (1960) Compressive properties of hard tooth tissues and some restorative materials. J Am Dent Assoc 60: 746-756

82. Pontius O, Hutter JW (2002) Survival rate and fracture strength of incisors restored with different post and core systems and endodontically treated incisors without coronoradicular reinforcement. J Endod 28: 710-715.

83. Chang WC, Millstein PL (1993) Effect of design of prefabricated post heads on core materials. J Prosthet Dent 69: 475-482.

84. Ferrari M, Mannocci F, Garcia C, Grandini S, Monticelli F, et al. (2002) New developments in the field of fiber dowels, $6^{\text {th }}$ International symposium on adhesive and restorative dentistry 14-17. 
Citation: Fahmy NZ (2012) Effect of Dowel Material and Design on the Fracture Resistance of Premolars. Dentistry 2:116. doi:10.4172/21611122.1000116

85. Bateman G, Ricketts DN, Saunders WP (2003) Fibre-based post systems: a review. Br Dent J 195: 43-48.

86. Mason PN (2001)New method for the execution of a composite resin core, $5^{\text {th }}$ International Symposium of Adhesive and Restorative dentistry 13-16.

87. Scotti R, Malferrari S, MonacoC (2002) Clarification on fiber dowels: prosthetic core restoration, pre-restorative endodontics, $6^{\text {th }}$ International Symposium of Adhesive and Restorative dentistry 7-11.

88. Sirimai S, Riis DN, Morgano SM (1999) An in vitro study of the fracture resistance and the incidence ofvertical root fracture of pulpless teeth restored with six post-and-coresystems. J Prosthet Dent 81: 262-269.

89. Lertchirakarn V, Palamara JE, Messer HH (2003) Patterns of vertical root fracture:factors affecting stress distribution in the root canal. J Endod 29: 523528.

90. Lovdahl PE, Nicholls JI (1977) Pin-retained amalgam cores vs. cast-gold dowel-cores. J Prosthet Dent 38: 507-514.

91. Kantor ME, Pines MS (1977) A comparative study of restorative techniques for pulpless teeth. J Prosthet Dent 38: 405-412.
92. Trope M, Maltz DO, Tronstad L (1985) Resistance to fracture of restored endodontically treated teeth. Endod Dent Traumatol 1: 108-111.

93. Guzy GE, Nicholls Jl (1979) In vitro comparison of intact endodontically treated teeth with and without endo-post reinforcement. J Prosthet Dent 42: 39-44

94. Greenfeld RS, Roydhouse RH, Marshall FJ, Schoner B (1989) A comparison of two post systems under applied compressive-shear loads. J Prosthet Dent 61: $17-24$

95. Dilmener FT, Sipahi C, Dalkiz M (2006) Resistance of three new esthetic postand-core systems to compressive loading. J Prosthet Dent 95: 130-136.

96. Chung K, Lin T, Wang F (1998) Flexural strength of a provisional resin material with fibre addition. J Oral Rehabil 25: 214-217.

97. Sorensen JA, Martinoff JT (1985) Endodontically treated teeth as abutments. $J$ Prosthet Dent 53: 631-636.

98. Varvara G, Perinetti G, Di lorio D, Murmura G, Caputi S (2007) In vitro evaluation of fracture resistance and failure mode of internally restored endodontically treated maxillary incisors with differing heights of residual dentin. J Prosthet Dent 98: 365-372. 